\title{
"WE ARE FORGOTTEN": THE PLIGHT OF PERSONS WITH DISABILITY IN YOUTH MINISTRY
}

\author{
Seyram Amenyedzi ${ }^{1}$ \\ Practical Theology and Missiology \\ Stellenbosch University
}

\begin{abstract}
Why are many churches in Africa inaccessible to persons with disability? This question has informed missiological qualitative research on the accessibility for persons with disability in churches in Ghana. Swinton (2002:29) coins the phrase the "forgotten dimension' of spirituality", which depicts the way persons with disability have been neglected in the ministry of many churches. Research in Ghana has proven that accessibility for persons with disability in churches is an afterthought reflecting exclusion from youth ministry as well. This article proposes to address the issue of inclusion/exclusion from a missio Dei perspective, challenging youth ministries to take deliberate steps to include persons with disability in their praxis.
\end{abstract}

Keywords: Disability; Persons with disability; Blind persons; Deaf persons; Persons with physical disability; Accessibility; Culture; missio Dei; Stigmatisation; Exclusion

\section{Introduction and background}

The starting point for theological discourse on disability is to accept that persons with disability are a marginalised group; they experience exclusion from conversations on Christian theology and ministry (Swinton 2011:274). Swinton (2002:29) calls the spiritual neglect of persons with disability the " "forgotten dimension' of spirituality" $\mathrm{He}$ states: "Despite evidence to suggest that a focus on the spiritual aspect of the lives of people with learning disabilities can be health-bringing and life-enhancing, this dimension of people's lives is often overlooked or considered irrelevant". Although he focuses on learning disabilities, it is evident from my research that this neglect can be generalized to all forms of disability (Amenyedzi 2016:149-161). He also says that the spiritual aspect of the lives of persons with disability is under-researched and misunderstood. This aspect of spirituality must be of great importance to service providers so that they can provide holistic support to persons with disability (Swinton 2002:29). It was Conner (2015:15) who said that "Christians have been supported by many different conversation partners from across the theological disciplines. Notably absent in this discussion have been contributions from the field of missiology". This neglect warrants a necessity for this missiological paper on disability.

Rev Dr Seyram B. Amenyedzi holds a PhD in Missiology (Disability Research) from Stellenbosch University. She is a research fellow at the Faculty of Theology, Stellenbosch University, South Africa, and a lecturer at the South African Theological Seminary. 
This paper has been presented twice at the International Association for the Study of Youth Ministry (IASYM) conferences: firstly, in Kenya (Africa conference) and secondly, in the United Kingdom as a keynote (International conference). This information is necessary to bear in mind while reflecting on Dr Amy Jacober' ${ }^{2}$ response to the paper at the international conference. Though the phrase "we are forgotten" is maintained in the heading, Jacober wonders if persons with disability are forgotten or could it be that churches do not know much about them or do not know what to do.

My motivation for disability research stems from my one-year national service experience in 1996 at the Cape Coast School for the Deaf in Ghana. I realised that the education of many deaf persons had come to abrupt end due to lack of accessibility to mainstream tertiary education. Furthermore, Pastor Nick Vujicic ${ }^{3}$, an Australian, who was born without limbs, but has an amazing international ministry, is a great inspiration for this research. His successful ministry depicts inclusion of persons with disability in pastoral ministry as a possibility. I am also motivated by the current trend of healing/miracle services coupled with testimonies of persons with disability on the media which project healing as what the church has to offer instead of accessibility.

This presentation captures an aspect of my $\mathrm{PhD}$ thesis: 'Equity and access for persons with disability in theological education, Ghana'. The concentration is on three groups of disability: blind persons, Deaf ${ }^{4}$ persons and persons with physical disability. This missiological contextual study explored the influence of Ghanaian culture on the stigmatisation leading to exclusion of persons with disability from society and churches which further influences their exclusion from theological education. This article is centred on two contexts: Ghanaian society and Ghanaian churches. The particular focus is on youth ministry but not theological education, which was originally included in the thesis.

The qualitative study employed various contextual methodologies: social constructionism $^{5}$, cultural research ${ }^{6}$ and some aspects of realistic evaluation (CMO: Context Mechanisms Outcome $)^{7}$. The research methods used were individual interviews, focus group interviews, and observation. The research was conducted in Ghana with a purposeful sampling size of 60 participants. The sample included 25 persons with disability: blind persons; deaf persons; and persons with physical disability who are

2 Dr Amy Jacober works with youth with disabilities. She is the author of Redefining Perfection: The Interplay between Theology \& Disability

3 Nick Vujicic. Life without limbs. [Online]. Viewed from: http://www.lifewithoutlimbs.org/. [Date accessed: May 2021].

4 "Deaf" refers to deaf persons who use Sign Language for communication

5 McLeod 1997:83. "Social constructionism" is a philosophical approach within the social sciences that considers the social and cultural contexts of a situation to explain a phenomenon. It focuses on how societies formulate perceived social realities, or in other words, how behaviours are formed within a society. This methodology was employed to explore how Ghanaian society constructs disability.

$6 \quad$ Marshall \& Gretchen 2010:24. A cultural research approach uses everyday life occurrences and phenomena to explore a research question. In order words, the culture of a particular group of people is used as a lens to inform data collection and analysis. Ghanaian perceptions and interpretation of disability in the culture and traditional belief system as a curse were used as a point of departure for this analysis.

7 Pawson \& Tilley 2005:365. The framework of Pawson and Tilley-the Context-Mechanism-Outcome (CMO) configurations pattern - aids in exploring the causes of the exclusion, what mechanisms are used, and how they can facilitate equal inclusion of persons with disability in theological education in the Ghanaian context. 
Christians, pastors, and/or church leaders; 24 church leaders (pastors from different denominations, including pastors and leaders from a church which includes deaf persons); six theological institutional heads, i.e., deans or presidents/vice presidents of theological institutions; and lastly, five disability experts. It must be noted that some of the participants were young people, especially the pastors and persons with disability. ATLAS.ti qualitative data analysis software was used to organise and manage data. Responses from participants are directly exported from ATLAS.ti software. Content analysis with a focus on constant comparative method was engaged in data analysis. Narration was also employed in the research; it is used more in this paper to make sense of experiences of persons with disability.

Various themes emerged, but for the purposes of this paper, I have chosen to focus my discussion on the following: social constructions of disability, the influence of culture and traditional belief systems on the stigmatisation and exclusion of persons with disability from society, stigmatisation and exclusion of persons with disability from churches (including youth ministry), and accessible youth ministry. The following section briefly explains disability from a missio Dei dimension.

\section{Missio Dei theology and disability}

The theological point of departure is the all-inclusivity of the missio Dei (God's Mission). Suess (2003:552) ${ }^{8}$ is of the opinion that, mission that is not linked to the missio $D e i$ is reduced to nothing. The term missio Dei historically is traced to Augustine in the light of the doctrine of the Trinity. However, from a missiological perspective, the concept of missio Dei was introduced at the Willingen conference in 1952. Karl Hartenstein may have coined the phrase in his report from Willingen, as it was not found in the original document. He spoke of mission as "participation in the sending of the Son, in the missio Dei, with an inclusive aim of establishing the Lordship of Christ over the whole redeemed creation" (Engelsviken 2003:482). Towards the latter part of the last century, there was a shift in the interpretation of the missio Dei, which connected the missio Dei, the church, and the kingdom of God. Despite the diverse views on the on the interpretation of missio Dei, Engelsviken (2003:486) argues that it is important to "hold the concepts of the trinitarian missio Dei and the kingdom of God together". The emphasis was now on the church as an instrument or agent of the missio Dei. The ancient church-centred missiology was theologically limited in that it did not fully realise the broadness of the missionary task as modelled, for example, by Jesus' own ministry to the poor, the suffering, and marginalised. Nor did it adequately take into account that Jesus' initial call to repentance and faith in the gospel because the kingdom of God was near (Mark 1:15) presupposes the temporal and substantial priority of the kingdom over the church, as well as the eschatological character of the kingdom, and therefore, also the mission of the church (Matthew 24:14). The church is part of the missio Dei, but the mission of the church cannot simply be identified with God's mission (Engelsviken (2003: 487).

8 This is the English version of Paulo Suess's original German paper as presented at the Willingen consultation, which was published by the WCC in 2003. Paulo Suess is theological advisor to the Brazilian Missionaries Council for Indigenous People and president of the International Association for Mission Studies. In 1987, he founded the first post-graduate course in Brazil for the study of missiology. 
Withworth (2012:8) identifies only one mission in Christianity, the missio Dei. Likewise, my argument is that Ghanaian Christian communities need to focus on accessibility for all people with disabilities in their praxes as this is how they can reflect holistic involvement in the missio Dei. Bosch (1991:390) sees mission as the missio Dei in the sense that 'Mission is an attribute of God'; God is a God of mission. It is God's mission that includes the church, not the church that has a mission to reach out to the world. The church is an instrument that God uses to reach out and express unconditional love to the world. Bosch (1991:393-401) stresses mission as mediating salvation, and this depicts mission as being holistic: salvation is not limited to the individual's relationship with Christ, but also considers the hatred, injustice, oppression, marginalisation, violence and other forms of suffering in the world as equally relevant. Likewise, mission as a quest for justice must focus on the tension of expressing unconditional love within a context that is filled with injustice. Salvation must be a source of joy and hope to everyone, especially the marginalised in society, which includes persons with disability. It is paramount for mission to resist any form of social injustice, discrimination, oppression, stigmatisation and exclusion, amongst others (Bosch 1991:393-401, 420, 432). Bosch (1991:28) said:

What amazes one again and again is the inclusivity of Jesus' mission. It embraces both the poor and the rich, both the oppressed and the oppressor, both the sinner and the devout, both the able-bodied and persons with disability. His mission is one of dissolving and down walls of hostility, of crossing boundaries between individuals and groups (italics mine).

Bevans \& Schroeder (2004:34) and Kritzinger (2011:50, 55) also highlight mission as the missio Dei. Bevans \& Schroeder (2004:34, 348) see mission as participation in the mission of the triune God, which can only proceed in dialogue (the prophetic dialogue). Mission as a prophetic dialogue is threefold: dialogue with the poor, culture, and other religions. Bevans \& Schroeder (2004:34, 71, 378, 285) and Kritzinger (2008:764, 767, 769) all stress contextualisation as an appropriate way for the church to engage in all inclusivity of the missio Dei. ${ }^{9}$ This study was a kind of dialogue among persons with disability, Ghanaian culture, and traditional religion. It essentially focuses on the influence of culture and traditional belief on stigmatisation and exclusion of persons with disability, reflecting prophetic dialogue.

Above indications clearly show that God is all-inclusive in reaching out to everyone regardless of gender, race, status, or disability. In other words, youth ministry as included in the church's praxis is also an instrument in God's Mission, which has a responsibility to be all-inclusive.

Youth ministry is vital in integrating teenagers and young adults into the church. Although some youth ministries are independent of the church, the primary purpose is to reach out to young people with the hope that they will have personal encounters with the Lord Jesus Christ and grow into responsible Christian adults. In his book Sustainable

The Prophetic dialogue (Bevans \& Schroeder, 2004:348) and the Pastoral/Praxis cycle by Kritzinger (2008:764, 767, 769), which is an intercultural/interreligious approach to contextualisation, are useful models to consider. 
Youth Ministry, DeVries (2008) highlights the ordeal of unsuccessful youth ministry in many churches despite their good programs and structures. He suggests that a sustainable youth ministry will require commitment and investment from the pastorate right down to youth workers and parents to succeed. I argue that in as much as they strive towards sustainable youth ministries, they must re-consider and endeavour that any form of discrimination and exclusion of persons with disability is abhorred. Only then can they claim to be fully involved in the missio Dei.

Bosch (1991: xv) has proposed that mission must bring transformation. Kritzinger (2011:52) is similarly of the opinion that, "Missiology-which critically reflects on mission-is 'encounterology,' the scholarly study of such transformative encounters". My focus as a missiologist is on advocating for transformation in any youth ministry praxis which excludes persons with disability.

\section{Social constructions of disability in Ghana: what is disability?}

It is indeed a very difficult task to define disability. Mackelprang (2010:88) identifies three models of disability: the moral model, the medical model, and the social model. The moral model links disability to sin and affliction, particularly within religious context. This model is evident by the way disability is culturally constructed as a curse or punishment in the Ghanaian traditional belief system and culture. The scientific medical model sees disability as a 'deficiency' and a medical condition. The medical model, despite refuting the claims of the moral model, makes persons with disability dependent on society and charity. Finally, the social model sees disability from another perspective, external societal barriers of discrimination, devaluation, stigmatisation, labelling, stereotype, exclusion, and inaccessibility. It seems that the social model has been hyped in such a way that it refuses to applaud the many successes achieved by the medical model in helping persons with disability. Imagine a world without all the medical accessibility interventions. As we acknowledge the positives of the medical model, it is necessary to uphold the social model as a catalyst for accessibility and inclusion. Deborah Creamer (2012:340-341), a renowned disability theologian, also recognises four models of disability. The first three are the same as those presented by Mackelprang (2010:88) — the moral, social, and medical model. However, Creamer adds a fourth, which is the "limits model of disability". This model questions perceptions of normalcy and disability, in that everyone experiences impairment at some point in their life, for instance, due to the ageing process. It encourages persons with disability not to be seen as the 'other,' because limits are normal. The limits model emphasises the positive aspects of disability, instead of the negative aspects. Unlike the social model of disability that focuses more on society, the limits model advocates embodiment. Louise Kretzschmar (2018:22) also pinpoints the perception of disability as a tragedy, where persons with disability are the 'victims', and the bio-psycho-social model. The biopsycho-social model "combines the biological (physical and medical), psychological (or emotional) factors and social (or environmental) factors.

To answer the question of what disability is, three different constructions of disability emerged from my research. Disability is socially constructed in Ghana as in the moral, medical, and social models. The first two were confirmatory, but the third is a significant finding, the social model indicating that disability is constructed as barriers in society. Empirical and unempirical evidence highlight that disability in the Ghanaian traditional 
belief system and culture is perceived as a curse meted out by the gods or ancestors due to abominations of a person with disability or a relative, or an ancestor. This reflects the moral model of disability. The study employing a cultural research methodology used this perception as the actual lens for enquiry. I sought to investigate whether or not this perception of disability as a curse has any influence on stigmatisation and exclusion of persons with disability. Indeed, this socio-cultural construction of disability as a curse has a major influence on stigmatisation leading to exclusion of persons with disability from society. Secondly, disability is socially constructed as in the medical model in that persons with disability are perceived as 'sick people'. In the Akan language, for instance, it is common for them to be referred to as "yarefo", which can be translated as "sick person".

The social construction of disability as in the social model connoting barriers in society is a very significant discovery for my thesis. Contextualisation employed in the study allowed a diversity of opinion; while society sees persons with disability as cursed and sick people, disability experts and persons with disabilities themselves strongly affirm societal barriers as the objects that disable them. One participant, a disability expert (who is also a blind person) explains disability as:

\section{P 3: DX_M_BP005.docx - 3:1 (8:8) (Super)}

\section{Codes: [social model of disability] [what is disability?] [context] [mechanism]}

I always, I resort to etymology here, and I take it like that if I use the prefix, the English prefix 'dis,' and I put in front of a word then it gives me the opposite of that word. So, if I have cover, I have covered something, and I put a 'dis' in front of it. 'Discover, ' then that is, I've removed the cover. If somebody is armed, he has his guns and things, and I put 'dis' in front of the word, and then, I have 'disarmed' the individual. Somebody has his comfort, I put 'dis' in front of the word, I have given him discomfort. You see, so I take it like this. So, if I have an ability, if I can read, if I have the ability to read and I'm given material in a format in which I can't read then it's like you are putting 'dis' in front of that ability to read and that becomes a 'disability' to me. You see, so if I can go up the stairs, I can go to a conference room to take part in a conference and there is a line of steps there and I am in a wheelchair, then that becomes a disability to me. So, it is the environment and the society that really puts the 'dis' in front of my ability. If I am provided with what I need then there is no 'dis' there, then my ability to function will stand, and then I can function alright. So, it depends on the angle you are coming from. But for me, practically, I will go back to what I said earlier on, that when your ability to do something is compromised, whether by society or by the environment, then that to me becomes disability.

The above participant uses language to express how society disables persons with disability due to inaccessibility and various barriers in the environment. The prefix 'dis' is significant in the construction of disability in that persons with disability actually have the ability to express themselves in many ways, but are rendered disabled once they are not able to access certain rights, privileges and resources in the environment and society. The social model of disability asserts that it is societal barriers that disable persons with disability, not the disability itself. As indicated above, if a blind person can access an 
audio or Braille book and a sighted person has a hard copy of the same book, both can access the same information. In the same way, if a wheelchair user can access a storey building via a lift or ramp, the wheelchair user's disability no longer matters in any significant way. Therefore, it is not disability that is the issue, but rather the barriers and inaccessibility in Ghanaian society that hinder persons with disability from full inclusion and participation in societal life. Contextualisation grants the opportunity to explore issues within several contexts. This contextual study has discovered that persons with disabilitys and disability experts respond differently to disability compared to Ghanaian society. "Therefore, in Ghana, the social construction of disability is not limited to the medical and moral models of disability" as usual, but also constructed as barriers as in the social model of disability (Amenyedzi 2016:122-123).

\section{Construction of disability within the Ghanaian Christian context}

The discussion above confirms the social construction of disability in Ghanaian society as sickness or disease or a curse as in the medical and moral models respectively. The significant new discovery for this research is that the social model of disability is not just some far-away theory, but very close to us. Disability is also constructed as barriers and inaccessibility in the Ghanaian environment and society. This section considers how disability is constructed in Ghanaian Christian communities.

Küster (2003:73) opines that people from various religious contexts "construct their religious identities over and over again" based on "their life stories and the continuous changing context". His proposal for a theology of dialogue between Christianity and other religions, which he calls inculturation, is most relevant in this case. Bosch (1991:454) raises the issue of the double movement in inculturation where there is "inculturation of Christianity and Christianization of culture". In short, inculturation is an aspect of contextualisation which focuses on dialogue between Christianity and culture.

Many pastors and most Christian leaders in Ghana perceive disability as in the medical and moral models. In their view, disability is a challenge, malfunction, deformity, and abnormality, connoting the medical model that sees disability as a malfunction and a condition that needs an intervention or cure. Most Christians in Ghana strongly link disability to demonic activity, such as witchcraft and curses, and it is therefore seen as unacceptable. Below are some pastors' views:

\section{P21: P010.docx - 21:1 (3:3) (Super)}

Codes: [what is disability?] [context] [mechanism]

Disability to me is a little bit of a deformity, any type of deformity.

\section{P23: P012.docx - 23:6 (17:17) (Super)}

\section{Codes: [curse] [traditions \& culture] [context] [mechanism]}

My view as a Christian, but I am also an African Christian, and I hold onto that view because I have seen it in some parts of my community — the god can punishbecause of a curse on the family. 
Another pastor said:

\section{P17: P006.docx - 17:7 (34:34) (Super) \\ Codes: [curse] [disability as a demonic activity] [traditions \& culture] [context] [mechanism]}

"Yes, yes!" Being an African I wouldn't doubt that at all, because there have been many instances where we have come into contact with such things. We've been in deliverance ministries where we pray for people, and we hear a whole lot of manifestations, and the Spirit of the Lord leads us to know what has transpired in the past and blah, blah, blah, and then. When we go to tackle that person as it were curse or what have you, the person receives instant healing.

There is an indication that some level of inculturation has taken place although there is no evidence that there has been a careful and deliberate dialogue between Christianity and culture regarding disability. "The cultural perceptions and social constructions of disability that are embedded in the traditional belief system seem to have been transported into the Christian belief system" (Amenyedzi 2016:122-126). Hence, there is the difficulty to differentiate between the way disability is constructed in the culture, Christianity, and the traditional belief system. Even though most Christian participants acknowledge the various causes of disability as medical conditions, diseases, and accidents, it is difficult to divorce themselves from the spiritual aspect. The African upholds African values and culture so much that it influences Christianity in many ways. To the typical Ghanaian, there is always a spiritual reason behind any occurrence, be it fortune or misfortune. Exorcism is therefore perceived as just normal. The traditionalist would consult a shrine and the Christian would seek for prayers. The current trend is for Christians to visit prophets for 'consultation' as it is popularly termed. Wuthnow (1992:37) undoubtedly connects religion and culture. Bevans and Schroeder (2004:348$395)$ in their prophetic dialogue propose intercultural dialogue and inculturation dialogue as important in contextualisation. Renowned Ghanaian female theologian Oduyoye cannot be left out in the conversation on inculturation. According to Oduyoye (2003:41, 42), "African culture is steeped in religion that is variously termed 'Traditional' ... social cultures are made up of a material way of life, but they also have spiritual components". I concur with Longchar (2011:47) when he suggests that disability theological reflections are done through the able-bodied lens; hence, the negative theology towards persons with disability. My doctoral research sought to do a dialogue between the culture, traditional belief system and Christianity regarding disability, and it is obvious how all these components influence each other. Indeed, it is evident that Ghanaians are steeped in culture as this is reflected even in the way disability is constructed in many churches. The response to disability is stigmatisation and exclusion.

The construction of disability as a disease or curse in most Christian communities in Ghana reflects stigmatisation leading to exclusion and lack of participation of persons with disability in their praxes. Pentecostalisation makes it even worse as this is not only limited to Pentecostal/Charismatic churches, but even among traditional orthodox contexts. There is constant healing-pressure on persons with disability who dare to show up at church or a Christian gathering. Persons with disability share stories of how pastors have changed their sermons to preach on faith and healing or have prayed for them when 
they went to church. There is usually such drama that they must be healed or else they are tagged as not having enough faith or as sinful. A typical example is the narrative presented below, which was published by the Ecumenical Disability Advocates Network (EDAN) - World Council of Churches: ${ }^{10}$

"The current trend in Ghana is for churches to organise healing/miracles services or schools. A church had organized a healing service which I followed closely on television even though I watched from another country".

Ten people with different kinds of diseases and disability were brought forward to be prayed for during the service. Two people got healed instantly; the preacher concluded they were healed because of their faith. A man with impairment in one eye had not yet been healed. The preacher laid hands on him, nothing happened; he then concluded that he lacked faith. The man explained he had a brain tumour which was the cause of the blindness. The preacher then laid hands and prayed again but the man did not see with the impaired eye. Then the man said he felt some lightness in the head. The preacher finally acclaimed: God heals whom He wants to! He continued to pray for the others when I went off.

I have personally always strongly asserted that I am not against supernatural healing as I have personally encountered God in this manner. I was healed of multiple fibroids some years back. As much as I have faith in God, my argument is that the pressure that is exerted on persons with disability to be healed is demeaning and stigmatising. This prevents them from going to church; they would rather stay away than be humiliated. There is a conflict of interest in such cases: a person with disability goes to church to worship but is rather perceived to have come for healing. Why is the faith of the person with disability questioned if no healing occurs? What about the faith of the minister? Not all biblical healing accounts depended on the faith of the person. In fact, sometimes the person healed had no faith; healing or miracles happened based on the faith of the prophet or Jesus Christ. Ghanaian churches are inaccessible and unwelcoming to persons with disability. This is reflected in the scarcity of accessible churches. In most cases, accessibility is an afterthought. It is common to see a wheelchair user carried over stairs every Sunday without that raising any alarm. It is uncommon to see Sign Language interpreters in churches; hence, Deaf persons are left out. Blind persons find it easier to access churches yet are faced with the daunting issue of stigma and exclusion.

Aside the socio-cultural influence on the construction of disability within the Ghanaian Christian community, the Bible also has a role to play. I regret to say that the Bible reinforces the culture and traditional belief system to stigmatise and exclude persons with disability from their praxes. Ghanaian pastors seem to be justified as they also recount biblical evidence of how healings and miracles occurred when persons with disability encountered the prophets, apostles, or Jesus Christ Himself. What then must they do as followers of Christ? If Jesus Christ and the apostles broke curses and brought healing, then they must also break curses and bring healing. They see exorcism as a biblical mandate rather than stigmatisation towards the person with disability. Undoubtedly, the Bible has influenced negative attitudes towards disability. Apart from

10 http://www.edan-wcc.org/index.php/the-news/news-update/itemlist/category/13-edan?limitstart=0 
the healing accounts, it is not hidden how disability has been meted out as punishments: persons with disability experience some exclusion from society and priestly duties, and these may have strongly justified negative attitudes and responses to disability in Christian communities. I concur with Githuku (2011: 86-87) who shares similar opinion with Claassens (2013:55) and others on the view that the Bible has influenced the exclusion of persons with disability from society. Kretzschmar (2018:38) emphasises the problem as the interpretations of some texts on disability in the Bible.

Yong (2011:49-56) and Wynn (2007:92) highlight a normate hermeneutic of disability where biblical texts on disability are interpreted from a dimension which reinforces discrimination towards persons with disability. "The normate hermeneutic is how scripture is interpreted so that it complies with, and reinforces socially constructed norms. This hermeneutic imposes a society's interpretation of disability on the text without due consideration of the text" (Wynn, 2007:92).

On the other hand, according to Reynolds (2008:34-35), it is true that the Bible has a lot of negative texts regarding persons with disability; likewise, there are some texts that are positive. For this reason, he proposes a hermeneutic of disability, where disability texts are interpreted in a way that will not cause more harm. Therefore, in Reynolds' proposal, the 'theological hermeneutic of disability' must consider the holistic, historical, cultural, social, and political frameworks from biblical times, as well as consider the current situation and context. Whereas the 'normate hermeneutic' problematises disability texts, the 'theological hermeneutic of disability' focuses on redemptive reading and interpretation of these text to reduce stigma and exclusion. I propose that Ghanaian pastors should consider this theological hermeneutic as a preferable way of engaging with disability texts. This will possibly reduce negative attitudes, especially that of exorcism, and this could potentially pave way for a focus on accessibility and the value of the personhood of persons with disability as human beings who are also created in the image of God. Swinton $(2011: 276,277)$ highlights how theology is exclusive and discriminating in such a way that persons with disability even seem to be strangers to God and our saviour, Jesus Christ. The vulnerability that persons with disability experience is not only social but also theological, and this leads to exclusion, which reduces their value and human dignity (Koopman 2013:45). Jacober (2017:8) is of the opinion that:

When we see that society at large is more inclusive towards our friends with disabilities than the church is, theologians must address the gaping holes and poorly writings of the past that relegate those with disabilities to a position of marginalization, oppression, isolation, and abuse. Let me be clear, I am not adopting theology to the worldwide trend of better treatment for and inclusion of those with disabilities. I am simply advocating that we catch up with what has been biblically and theologically present, seeking a better theology that addresses the wide spectrum of disability.

The bottom line is that we must value and accept persons with disability for who they are and ensure that our theology and praxes are equally inclusive of them. 


\section{Disability and youth ministry in Ghana}

The different models of disability, socio cultural constructions of disability and Christian perspectives and attitudes towards persons with disability in Ghana as discussed earlier depict stigma, exclusion, and lack of participation.

I tend to pose the following questions for reflection as I address disability and youth ministry in Ghana: What is the plight of the Ghanaian youth with disability amid such socio-cultural and theological views on disability? Who is the African youth with disability? What is the missiological focus of youth ministry? How accessible are our youth ministries? What deliberate plans do we have to include and integrate persons with disability? These questions are specific to the Ghanaian context, but I would encourage each youth worker to customise them to their relevant context.

It is quite daunting to define who a youth is within an age range. Different institutions and cultures have their own definition of who a youth is. While some look at age, others consider dependency and responsibility as the yardstick. A youth is a person who is at a stage of life between childhood and adulthood. Adolescence is often used interchangeably with youth; while youthfulness includes adolescence, it is much more than adolescence. Adolescence, also known as puberty, is a phase in a young person's development in which occur several physical changes and development. At this stage, the experiences of young people cannot be clamped together as one. Every youth's identity is formed around environment, culture, exposure, education, and spirituality, among others. In Ghana, age, dependency or independence and marriage are relevant factors that come into play in defining a youth. A young person who is employed and married may be considered an adult whereas another person of the same age or older who is unemployed and still putting up with family may be considered a youth. It is necessary to note that each youth has unique individual experiences despite the several commonalities. In Ghana, it is common to exclude the youth from major decisionmaking at family and public levels.

The Ghanaian youth with a disability, aside every other general experience of young people, must grapple with social constructions and attitudes of stigma, exclusion, and inaccessibility. In Ghana, a person with disability is perceived as cursed or sick and therefore suffers stigmatisation and exclusion from society and Christian communities. Being a youth may mean exclusion, but having a disability further makes the experiences quite unique and enormous.

It is rare to see a church without a youth ministry; some have completely different youth services from adults and others have joint services with the adults, but have their separate youth ministry meetings as well. My focus at this point is on how accessible our youth ministries in Ghana are. Young people with disability indicate that they would prefer to stay at home rather than go to church due to experiences of stigma, exclusion, and inaccessibility. If churches are inaccessible, then it is also true that ministries within the church are equally inaccessible, youth ministry being no exception. A young person recalled reactions from his church after a Bible reading. He was given a lift home because this man was so amazed that he could read. Someone wanted his Braille Bible to keep as a souvenir. The blind youth was surprised as reading for him was normal. Disability has always been associated with abnormality to the extent that even what is normal to a person with disability looks special and 'supernormal' to people. 
In another church, a blind youth was fully involved in church as leader of a singing group. He was the only one in the group with a disability, and this group was doing well. It took him a long time to get this far because he had a bitter experience of stigma and exclusion from this church in the past but was determined to serve God regardless of what would happen. He was at this point of my study blessed with a pastor who believed in him and allowed him to participate. This is to shout as loud as possible that if granted access, youth with disability can worship God comfortably and participate in the praxes of the church and youth ministry. In another instance, a church which includes deaf persons that was observed also saw some active young members who were deaf. Issues of stigma, exclusion and lack of participation were not absent; the members who were deaf met separately though they had joint service once in a month. The leadership of the church did not include any deaf member, and marriages were usually between deaf persons. I repose these questions for reflection: What is the missiological focus of youth ministries? How accessible are our youth ministries?

\section{Accessible youth ministry}

God has a mission to reach out to everyone regardless of race, age, gender, or disability. I argue that unless youth ministries in Ghana are accessible to persons with disability, they cannot claim to be fully involved in the missio Dei. To start with, youth ministries in Ghana must admit that they are inaccessible to persons with disability. They are actually "forgotten" as Swinton (2002:29) puts it. But according to Jacober (2019), they might not even know what to do about persons with disability, let alone to have forgotten them. Since youth ministry is not separate from the church, it is paramount to address the church. Moreover, this is also applicable to parachurch youth organisations. What is the missiological focus of the church and youth ministries in particular? This is a wakeup call to Christian leaders to reconsider their missiological focus. The great commission is a mandate to go to every place and to reach out to everyone. God's love is for all; He does not discriminate. The focus first and foremost must be on accessibility rather than healing. The primary mandate is to preach repentance and remission of sin. Healing becomes a bonus (Matthew 28:8-20; Mark 16:15-18; Luke 24:44-49; John 20:19-23; 2 Corinthians 5:17-21, John 3:16). If the Ghanaian church has an all-inclusive mission focus, then its ministries, which include youth ministry, will have access to persons with disability. Youth workers! Youth pastors! Youth leaders! the time is now; it is never too late to begin the disability dialogue. This also implies that intentional plans are to be made to train youth workers, youth pastors, and leaders in disability awareness to be able to include and integrate persons with disability.

Often, accessibility is an afterthought, as it is only when a person with disability appears that some considerations are made. In fact, in most cases, there is no response at all to their peculiar needs. It is better to be proactive than reactive. So why not begin the accessibility conversation now? There is a need to consult stakeholders on accessibility plans. There are required standards for our environment to be disability-friendly. Below are some practical accessibility tips: 
Practical tips for becoming a disability-friendly church [and youth ministry] modified from RAMP UP and DisAbility Connextion (Möller \& Watt) ${ }^{11}$

1. Provide a warm, friendly, and welcoming environment: Greet persons with disabilities as you would anybody else. Communicate that people affected by disabilities are loved, belong, and are included in your church/youth ministry.

2. Provide basic disability awareness training for youth, church staff, and volunteers: Review basic disability etiquette tips. Invite a disability expert to your church. Obtain disability ministry resources. Ask persons with disabilities what they need.

3. Improve accessibility. Make modifications where necessary: ASK people with different disabilities about their needs, especially regarding difficulties they face at the premises and make the necessary changes. If necessary, modify access to the main entrance, the sanctuary, restrooms, and classrooms. Accessible parking close to the entrance is very helpful.

4. Provide opportunities for service to persons with disability: Include them in the leadership of the youth ministry. Utilise their services as ushers or greeters, or to serve communion. Invite persons with disabilities to read the scriptures, share their testimony, or to be part of worship and prayer teams.

5. Provide disability friendly materials: Have large print Bibles available. Print song sheets for people with visual impairment. Consider providing assistive listening devices for persons with a hearing impairment as well as Braille facilities to translate lecture notes/textbooks and an audio library.

6. Provide space for wheelchair users throughout the sanctuary/meeting places: Shorten a few pews or take chairs away from some rows so wheelchair users can sit with their families and friends.

7. Provide a Sign Language interpreter for Deaf persons: Place a sign interpreter in a well-lit area that is visible from every angle.

8. General communication and interaction tips: Treat persons with disabilities with respect, in the same way as you would treat any other human being. Speak directly to them, not via their family or caregivers. Remain relaxed and try not to be awkward. Do not get caught up with fancy euphemisms, such as 'physically challenged' or 'differently abled'. Put the person first, not their disability.

9. Aid in accessible parking areas: Have an attendant available to help persons with disabilities from their vehicles. Offer to push their wheelchairs if needed. Have a wheelchair available to assist those with mobility difficulties.

10. Provide a 'buddy' or mentor for those who might need assistance: Utilise assistants to help persons with disabilities in worship services.

Add prayer to the above tips to be a welcoming and accessible church/youth ministry in Ghana.

1 RAMP UP and DisAbility Connextion are ministries that create disability awareness in Christian communities. 


\section{Some changing scenes regarding disability in Ghana.}

While the stigma, discrimination, and exclusion of people with disabilities in Ghana remains an ordeal, it is heart-warming to see some encouraging steps being taken towards inclusion. The Presidential State of the Nation address and Ministry of Information press conferences have recently introduced Sign Language interpretation, a step in the right direction. These programs are now accessible to our brothers and sisters who are Deaf. I have also observed a recent television program on disability where persons with disability are the main guests on the show. This platform allows them to share experiences and to explain their needs to the public, and this can potentially enhance inclusion and accessibility.

\section{Conclusion}

The paper "We are forgotten": The Plight of Persons with Disability in Youth Ministry sought to provoke thoughts and conversations about disability accessibility in Ghanaian Christian communities with a particular focus on youth ministry. It is evident through empirical research that persons with disability in Ghana experience stigmatisation leading to exclusion and lack of participation in societal life. The socio-cultural construction of disability as a curse, which is embedded in the culture and traditional belief system, has a major influence on such experiences of persons with disability. Since religion and culture affect each other in several ways, the way disability is constructed in the culture is similar in the Christian context. It is unfortunate that persons with disability in Christian communities are perceived as cursed and that exorcism, rather than accessibility, is a common reaction to disability. It is all too common that youth ministries in Ghana are inaccessible to persons with disability. There is a call for Christian leaders and youth workers to reconsider their missiological focus as the missio $D e i$ is all-inclusive. Hence, it is only when their praxes include persons with disability that they can claim to be fully involved in the missio Dei.

To this end, let us consider the following verses for reflection:

"'Cursed is anyone who leads the blind astray on the road.'

Then all the people shall say, 'Amen!'” (Deuteronomy 27:18, NIV).

"Do not curse the deaf or put a stumbling block in front of the blind, but fear your God. I am the Lord" (Leviticus 19:14, NIV).

\section{BIBLIOGRAPHY}

Amenyedzi, B.S. 2016. Equity and access for persons with disability in Theological Education, Ghana. PhD Dissertation. Stellenbosch: Stellenbosch University. Amenyedzi, B.S. 2018. Disability and healing: Healing trends in Ghana: http://www.edan-wcc.org/index.php/the-news/news-update/itemlist/category/13edan?limitstart $=0$

Avoke, M. 2002. Models of disability in the labeling and attitudinal discourse in Ghana, Disability \& Society 17(7): 769-777. 
Baffoe, M. 2013. Stigma, discrimination \& marginalization: Gateways to Oppression of persons with Disabilities in Ghana, West Africa, Journal of Educational and Social Research 3(1): 187-198.

Barron, L. 2006. The SAGE dictionary of social research mMethods. London: Sage.

Bevans, S.B. \& Schroeder, R.P. 2004. Constants in context: A theology of mission for today. New York: Orbis.

Biblesoft. 2006. International standard Bible encyclopedia (ISBE) Online. Electronic Database.

Bosch, D.J. 1991. Transforming missions: Paradigm shifts in theology of missions. New York: Orbis.

Brierley, D. 2003. What every volunteer youth worker should know. Cumbria: Spring Harvest \& Authentic Lifestyle.

Claassens, L. J. M. 2013. Job, theology, and disability. Moving towards a new kind of speech. In Claassens, J, Swartz, L., \& Hansen, L, (eds.), Searching for dignity: Conversations on human dignity, theology, and disability. Stellenbosch: Sun Media, 55-66.

Conner, B.T. 2015. Enabling witness: Disability in missiological perspective. Journal of Disability \& Religion 19(1): 15-29.

Creamer, D. 2003. Toward a theology that includes the human experience of disability, Journal of Religion, Disability \& Health 7(3): 57-67.

Creamer, D.B. 2012. Disability Theology, Religion compass 6(7): 399-346.

Creswell, J.W. 2012. Educational research: planning, conducting, and evaluating quantitative and qualitative research. Boston: Pearson.

DeVries, M. (2008). Sustainable youth ministry. Downers Grove IL: IVP.

Eastland, N. 2005. Encountering the disabled God, PMLA 120(1): 584-586.

Engelvisken, T. 2003. Missio Dei: the understanding and misunderstanding of a theological concept in European Churches and Missiology, International Review of Missions 92(367): 481-497.

Ghana Federation of the Disabled. 2008. The disability situation in Ghana [Online]. Viewed from:www.gfdgh.org/disability\%20in\%20ghana.html [Date accessed: 1 March 2015].

Goffman, E. 1963. "Stigma and social identity”. Stigma: Notes on the management of the spoiled identity. New York: Simon \& Schuster.

Jacober, A. E. 2017. Redefining perfect: The interplay between theology \& disability. Eugene, OR: Cascade.

Kabue, Mombo, Galgalo \& Peter 2011 (eds). Disability, society, and theology: Voices from Africa. Kenya: Zapf Chancery.

Kabue, S. 2011. Persons with disabilities in church and society: A historical and sociological perspective. In Kabue, S., Mombo, E., Galgalo, J., \& Peter, C.B. (eds.), Disability, society and theology: Voices from Africa. Kenya: Zapf Chancery, 3-23.

Koopman, N. 2013. Hope, vulnerability, and disability? A theological perspective. In Claassens, J., Swartz, L., \& Hansen, L. (eds.), Searching for dignity: Conversations on human dignity, theology, and disability. Stellenbosch: Sun Media, 43-54.

Kretzschmar, Louise. 2018. The Church and disability. Pietermaritzburg: Cluster. 
Kritzinger, J.N.J. 2008. Faith to faith - Missiology as encounterology, Verbum et Ecclesia 29(3): 764-790.

Küster, V. 2003. Towards an intercultural theology; Paradigm shifts in missiology, ecumenical and comparative religion,' In Mortensen, V. (ed.), Theology and religions: A dialogue. Cambridge: Eerdmans, 171-184.

Küster, V. 2004. Who, with whom, about what? Exploring the landscape of interreligious dialogue, Exchange 33(1): 73-92.

Küster, V. 2005. The Project of an Intercultural Theology, Swedish Missiological Themes (93)3: 417-432.

Longchar, A.W. 2011. Sin, Suffering, and Disability in God's World. In Kabue, S., Mombo, E., Galgalo, J., \& Peter, C.B. (eds.), Disability, society and theology: Voices from Africa. Kenya: Zapf Chancery, 47-58.

Mackelprang, R.W. 2010. Disability controversies: Past, present, and future. Journal of Social Work in Disability \& Rehabilitation 9(2-3): 87-98.

Marshall, C. \& Gretchen, B. 2010. Designing qualitative research. California: Sage.

McLeod, J. 1997. Narrative and psychotherapy: Narrative therapy from a social constructionist perspective. London: SAGE Research Methods.

Möller, E. \& Watt, B. (n.d.). Are people with disabilities at home in the church? [Pamphlet]. Christian Literature Fund.

Oduyoye, M. A. 1993 Contextualization as a Dynamic in Theological Education. In Schuller, D.S., King, G.B., Merrill, N., Morse, L. Globalization, tracing the journey, charting the course (Theological Education, Supplement 1:XXX). Pennsylvania: ATS.

Oduyoye, M.A. 2003. African culture and the Gospel: Inculturation from an African woman's perspective. In Oduyoye, M.A. \& Vroom, H.M. (eds.), One Gospelmany cultures: Case studies and reflections on cross-cultural theology. New York: Rodopi, 39-62.

Olyan, M.S. 2008. Disability in the Hebrew Bible: interpreting mental and physical differences. New York: Cambridge University Press.

Pawson, R. \& Tilley, N. 2005. Realistic Evaluation. In Mathison. S. (ed.), Encyclopedia of Evaluation. Thousand Oaks, CA: Sage, 363-368.

Pawson, R. and Tilley, N. 2004. Realistic evaluation. London: Sage.

Saldaña, J. 2009. The coding manual for qualitative researchers. London: Sage.

Slikker. J. 2009. Attitudes towards persons with disability in Ghana. VSO, sharing skills, Changing Lives, Ghana Volunteer May 2009.

Suess, P. 2003. Missio Dei and the project of Jesus: the poor and the "other" as mediators of the kingdom of God and protagonists of the churches, International Review of Mission, 92(367): 550-559.

Swinton, J. \& Mowat, H. 2006. Practical theology and qualitative research. London: SCM Press.

Swinton, J. 2001. Building a church for strangers, Journal of Religion, Disability \& Health, 4(4): 25-63.

Swinton, J. 2002. Spirituality and the lives of people with learning Disabilities'. Tizard Learning Disability Review 7(4), 29-35.

Swinton, J. 2002. Spirituality and the lives of people with learning Disabilities'. Tizard Learning Disability Review 7(4): 29-35. 
Swinton, J. 2007. Forgetting whose we are, Journal of Religion, Disability \& Health, 11(1): 37-63.

Swinton, J. 2011. Who is the God we worship? Theologies of disability; challenges and new Possibilities'. International Journal of Practical Theology 14(2): 273 - 307.

Swinton, J., 2006. Identity and resistance: why spiritual care needs "enemies". Journal of Clinical Nursing, 15(7): 918-928.

Swinton, J., 2008. Disability \& forgetting whose we are: Theological reflections on personhood, faith and dementia, Journal of Religion, Disability \& Health 11(1): $7-41$.

Swinton, J., Mowat, H. \& Baines, S. 2011. Whose story am I? Re-describing profound intellectual disability in the Kingdom of God, Journal of Religion, Disability \& Health 15(1): 5-19.

Swinton. J. 1997. 'Restoring the Image: Spirituality, faith, and cognitive disability, Journal of Religion and Health 36(1): 21-28.

Takyi, E. 2013. Barriers to mainstream participation of persons with disabilities: a qualitative study of persons with physical disabilities in Techiman, Ghana. Master's thesis, Department of Psychology, Norwegian University of Science and Technology.

The Holy Bible. 1999. King James Version. New York: American Bible Society.

The Holy Bible. 2011 New International Version: Biblica.

United Nations. (n.d). The UN Convention on the rights of persons with disabilities [Online]. Viewed from: www.un.org/disabilities/convention. [Date accessed: April 2013].

Vujicic, N. (n.d.). Life without limbs. From no limbs to no limits [Online]. Viewed from: www.lifewithoutlimbs.org. [Date accessed: May 2021].

Whitworth, D.M. 2012. Missio Dei and the means of grace. Doctoral thesis, School of Arts, Histories and Cultures, University of Manchester.

Wuthnow, R. 1987. Meaning and moral order: Explorations in cultural analysis. London: University of California Press.

Wuthnow, R. 1992. Rediscovering the sacred: Perspectives on religion in contemporary society. Michigan: Eerdmans.

Wynn, K.H. 2007. The normate hermeneutic and interpretations of disability within the Yahwistic narratives. In Avalos, H., Melcher, S.J. \& Schipper, J. (eds.), This abled body: rethinking disabilities in biblical studies . Atlanta: Society of Biblical Literature, 91-99.

Yates, T. 1994. Christian mission in the Twentieth Century. Cambridge: Cambridge.

Yong, A. 2007. Theology and down syndrome: reimagining disability in late modernity. Texas: Baylor University Press.

Yong, A. 2011. The Bible, disability, and the church: a new vision of the people of God. Grand Rapids, Michigan: W.B. Eerdmans. 